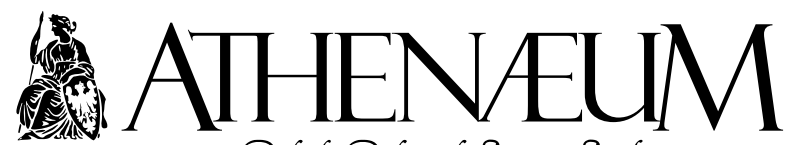

Polish Political Science Studies

Polskie Studia Politologiczne

\title{
ACTIONS OF THE CITY GUARD IN TORUŃ TOWARDS RESIDENTS' PERSONAL SAFETY: SELF-DEFENCE COURSES FOR WOMEN*
}

\author{
DZIAŁANIA TORUŃSKIEJ STRAŻY MIEJSKIEJ W ZAKRESIE \\ ZAPEWNIENIA BEZPIECZEŃSTWA INDYWIDUALNEGO \\ NA PRZYKŁADZIE KURSÓW SAMOOBRONY DLA KOBIET
}

Katarzyna Amrozy*

\begin{abstract}
- ABSTRACT
The article presents main assumptions about self-defence, particularly trainings aimed at educating women, with special focus on actions initiated by the City Guard in Torun. The Jestem bezpieczna [I Am Safe] self-defence courses for women, organized since 2006, are an important element in strengthening individual security of female residents of Toruń. Although at times such courses are subject to criticism, they have their undeniable advantages, which are specified in this article.
\end{abstract}

Keywords: women's security; self-defence; individual security; personal security; sense of security; city guard

\section{- ABSTRAKT -}

W artykule przedstawiono główne założenia dotyczące samoobrony, zwłaszcza szkoleń ukierunkowanych na edukowanie kobiet, ze szczególnym uwzględnieniem działań inicjowanych przez toruńską Straż Miejską. Organizowane od 2006 roku kursy samoobrony dla kobiet pod nazwą "Jestem bezpieczna” stanowią ważny element kształtowania bezpieczeństwa indywidualnego wśród mieszkanek Torunia. Choć przeprowadzanie takich zajęć bywa poddawane krytyce, wiąże się jednocześnie $\mathrm{z}$ niewątpliwymi zaletami, co wyszczególniono w niniejszym tekście.

Słowa kluczowe: bezpieczeństwo kobiet; samoobrona; bezpieczeństwo indywidualne; bezpieczeństwo osobiste; poczucie bezpieczeństwa; straż miejska

* The author participated in the Jestem bezpieczna [I Am Safe] course in 2014 and 2015. Moreover, the author has trained aikido, judo, and now she is practicing Krav Maga. She has also participated in Combat 56 and STAY AWAY seminars.

** Nicolaus Copernicus University, Faculty of Political Science and Security Studies, Toruń, Poland. 
The issue of self-defence, including methods tailored specifically for women, has enjoyed keen interest for a dozen of years. Such trainings are organized by most training schools of martial arts and it is hard to estimate the number of participants in these special courses. More and more often, actions are being taken to eliminate the risk of certain dangerous situations. Such measures include getting a guard dog, installing alarms, obtaining a gun permit, buying pepper spray or a stun gun, and attending special self-defence courses. It is impossible to be fully prepared for every threat, which does not change the fact that prevention and so-called situational awareness are important elements of education for individual security. There is also an increasing number of books on personal security issues which aim at preparing readers for threats that are not only the physical but also the mental ones (although attempting to learn any techniques from photos or without practicing them will not bring any effect).

The aim of this article is to provide an overview of courses organized by the City Guard in Torun as part of broadly understood self-defence training for women, in particular the Jestem bezpieczna course. Such actions fall within the scope of individual (personal) and structural security. The article also presents any potential benefits of attending self-defence classes.

\section{INDIVIDUAL (PERSONAL) AND STRUCTURAL SECURITY}

Self-defence is one of the elements of individual security (also known as personal security or self-security), and in a broader sense - structural security. According to Witold Pokruszyński (2011), personal security refers to the safety of a person, with all of his/her material and spiritual values. In turn, structural security refers to the organizational and institutional aspects of social life in a local, regional, state and international context. The main reference point of individual security is a person, his/her needs, and methods of satisfying them. These two dimensions can converge and overlap, which is visible in self-defence classes organized by public institutions - the police, city guard, and the Ministry of National Defence - which in this way fulfil their role to serve the society, using their experience and sharing it in a specific way. What also comes as important are preventive actions - campaigns (online, television) ${ }^{1}$ or programmes targeted at

\footnotetext{
${ }^{1}$ For example, the $4 \mathrm{U}$ campaign (implemented by the Internal Security Agency) regarding threats caused by terrorist attacks and by individual perpetrators, the HAZARD? Nie, dziękuje [GAMBLING?
} 
specific entities. Involvement in such initiatives can increase the citizens' sense of security, both personal and in the place of residence, and will probably increase the willingness to cooperate with judicial authorities. Both the individual and the structural approach depart from the assumption that the state is the main entity to ensure the security of its citizens, and recognize that each individual, by using available means, becomes equally responsible for their own protection.

The sense of personal security depends on many factors: the environment in which a person grew up; own (or our relatives') experience; mentality; psychological and intellectual predispositions; assessment of the activities of law enforcement services and the judiciary; general situational awareness. Another element are the exaggerated images created by the mass media, often full of brutality and abundant in descriptions of violent cases; however, generally the number of such crimes is not high, and smaller, less spectacular illegal acts are more troublesome.

\section{SELF-DEFENCE}

At the beginning it should be emphasized that self-defence is not synonymous with any particular systems, sports, or martial arts. Generally, self-defence draws on the achievements in these fields, but it emphasises other elements and adapts to the needs of its recipients - in this case, women. Self-defence has not been clearly defined. Individual authors draw attention to its various aspects, which is often motivated by their own experience gained during training a specific discipline. According to Artur Litwiniuk and Wojciech Cynarski (2003), it is a combat system based on grappling and throws that has defensive application in various specific situations and life circumstances. Grappling defence techniques are adequately adapted not only to various types of attack but also to the conditions of combat and defence against a physically stronger or armed opponent. The above definition seems too narrow as it limits self-defence to the knowledge of grappling and throwing techniques, which not always can be used. Moreover, they require precision, and if an attacked person fails to perform them correctly, it is difficult to proceed with any further activities, which gener-

No, Thank You] campaign (prepared by the National Revenue Administration) aimed at raising the awareness of addictions and gambling. 
ates additional stress. In turn, for Jan Harasymowicz (2003) self-defence means a self-preservation act or action taken by a person in a situation of danger and a direct attack on his/her health, life or own good; however, he does not specify what such act or action is based on. Jacek Sikora and Grzegorz Domaradzki (2011) define self-defence in a more precise way as they say that this is not a sport discipline or discipline, but only a practical skill, the acquisition of which is one of the goals of martial arts and sports training. It is based on selected basic techniques characteristic of a given hand-to-hand combat style (judo, karate, ju-jitsu, aikido, kung-fu, taekwondo, etc.), and its task is to parry, avoid, weaken or neutralize the opponent's attack and to overpower and immobilize the attacker in response to the attack. A similar definition is presented by Konrad Raczkowski (2008), according to which self-defence is a kind of compilation of useful techniques, derived from various systems, martial arts and sports, which combined with appropriate tactics of defence action (also verbal) give an opportunity to avoid physical confrontation with an aggressor or make it possible to successfully parry the attack of one or many people. A few points in the above approaches deserve attention - emphasis on drawing from other disciplines with regard to their practical application and without focusing on specific and complicated names of techniques. Most importantly, self-defence understood in this way does not mean the need for physically confronting or overpowering the attacker. It becomes more important to avoid the fight and only to parry attacks as the last resort.

Defence actions should be based on simplicity and economy of movements; preferably, their performance should be guided by instinctive reactions, despite some physical limitations. During the classes, it is also worth making the participants aware of the possibility of counterattacking with everyday objects (keys, handbag, umbrella, etc.) or special tools such as pepper spray, an expandable baton, the Kubotan (Jak używać kubotanu?; How to use the Kubotan?). It is much more beneficial if participation in training is voluntary. Other issues that are important for any training, not only in self-defence, are regularity, repetition, and humbleness. What can be the motivation to participate in training? It is mainly about the desire to improve the sense of security, agility, mental strength, preparation for potential dangerous situations. For other participants, this can be a form of preparation for recruitment to law enforcement services. Another group of people who attend classes are victims of various crimes (assault, theft, harassment, rape, sexual and physical violence, inappropriate behaviour in public space). 
Skills acquired during self-defence classes are not limited to physical fitness. First of all, the training regards situational awareness of threats (understood as careful avoidance of certain situations), deciding on alternative solutions (for example, ordering a taxi instead of lonely walking back), trusting one's intuition and taking preemptive action when noticing danger. At the same time, the participants are warned against exaggeration that leads to refraining from any activities, and on the other hand - against feeling "immortal" and believing that participation in the course will protect them against all threats. When asked what she teaches at self-defence courses, a Krav Maga instructor Anna Krupska said that she trains the participants in gaining time and space for themselves - a distance that will allow them to act. During the course women learn to effectively ask for help, look for a solution even in a difficult situation, e.g., get into the range of CCTV cameras, as a self-defence course has to touch many aspects to be complete. It must build physical fitness, improve coordination, and make the participants familiar with their bodies so that they are able to maintain balance or fall in the safest way. The course teaches techniques (what to do when the attacker attempts to punch) and tactics - where to stand, which way to turn, how to shield your child. The course also works on the mental component. It helps believe in oneself, in one's abilities (Ludwinek-Zarzeka \& Krupska, 2017). According to Monika Kowalska and Mirosław Michalski (2014), the participants also learn how to deal with fatigue and stress, how to control their emotions and act with maximum rationality and efficiency in the face of danger and under the influence of strong stress, emotions and fatigue. All this is based on a strong will, desire to survive and to overcome one's own weakness. It is also a good idea if self-defence courses discuss pre-medical first aid and legal provisions regarding self-defence. In special cases, centres tasked with helping female victims may also be invited to help with such initiatives.

\section{SELF-DEFENCE COURSES FOR WOMEN}

Organizing self-defence courses addressed specially to women is sometimes criticized, e.g., by aforementioned Konrad Raczkowski (2008), who says that the advertised and promoted so-called "quick self-defence courses" addressed specifically to women are "a fiction". Although they present to the participants certain dangerous situations and ways of neutralizing them, they do not achieve permanent changes in psychological and motor spheres. Great interest in such 
training is related to the commercialization of the issue of individual security, which can result in a lower level of quality of such classes as they might lack necessary elements and approach the issue with nonchalance, use anachronistic and complicated techniques as well as promise $100 \%$ efficiency. Self-defence classes are accused of not reflecting the realities of a true fight - in everyday situations we may not be wearing tracksuits and comfortable shoes, and we may be more distracted; in other words - we are not in artificially created optimal conditions. Opponents of self-defence courses for women also argue that in this way, women will already be put in the role of a victim (Höller, Maluschka, \& Reinisch, 2010), and the very issue of women's personal security (and other groups that are at increased risk of violence: children, teenagers, the elderly, the disabled) is neglected. It is also argued that self-defence courses are organized mainly in large cities, which, due to commuting and the resulting costs, excludes female residents of smaller towns. Others say that such workshops only serve marketing and PR purposes, promoting law enforcement services and their command.

Up to a certain level, a well-organized training can prepare the participants to properly respond in an unexpected situation. It is not only about skills within individual techniques, but also about developing instinctive reactions, reducing inhibitions to use violence and aggression, and understanding the potentially paralyzing fear. The courses are also not intended to teach the participants how to respond to every possible threat as it is neither possible nor real. Contrary to one of the above opinions, self-defence courses teach women to step out of the role of a victim in everyday life, and not to perpetuate this stereotype. This is one of the first steps towards further development in the area of personal security, a point of reference that can be expanded to other, more specialized, trainings. As in the case of other disciplines, the training process does not end when one leaves the mat (Larkin, 2020). What the participants get from the classes depends on themselves - their willingness, approach to the exercises, expectations towards the seminar, preparation for mental change - as well as on the instructors - their training, skills, and approach to the participants. Such actions, undertaken to ensure the safety of an individual and their relatives, make sense even if no circumstances to use the learned skills ever occur: any such course is valuable, even if it lasts a short time. Of course, the knowledge acquired from the course needs to be broadened, but it is worth trying, searching, finding out as there is a chance this will cause a change in one's life (Ludwinek-Zarzeka \& Krupska, 2017). 
Contrary to a popular but erroneous belief, there is no such thing as a "victim type". Some people perpetuate the opinion that women can avoid being raped by avoiding dangerous places or wearing less provocative clothing. Yet rape occurs regardless of the time of day, and at any age or in any social group. All statistics and research show that there is no such thing as a "typical rape" or "typical rape victim". Such attacks simply cannot be predicted (Samoobrona dla kobiet, 2020). Some other contemporary threats (e.g., terrorist attacks or attacks by an active shooter) are also characterized by randomness and unpredictability in the selection of victims - sometimes it is enough to be in the wrong place at the wrong time. Therefore emphasis should be placed on the psychological dimension of self-defence and on the instructor helping build the right attitudes. Training with different people, also with the instructor, to some extent familiarizes the participants with potential forms of aggression and violence. Varied classes which take place not only in the training room but also, e.g., on public transport, in the square, in the basement, are also beneficial.

\section{JESTEM BEZPIECZNA [I AM SAFE] COURSE}

Since 2006, the free Jestem bezpieczna course has been organized annually (except 2018) by the City Guard in Torun. This is one of the many tasks carried out by this service, which affects its image among the community. The City Guard website has reports on their activities since 2012, which are included in the table below.

Table 1. The Jestem bezpieczna Self-Defence Course

\begin{tabular}{|l|l|l|l|l|}
\hline Year & Edition & $\begin{array}{l}\text { Number of parti- } \\
\text { cipants/how many } \\
\text { finished }\end{array}$ & Target group & Date \\
\hline $\mathbf{2 0 1 2}$ & X & $61 / 45$ & NCU female students & no info \\
\hline \multirow{2}{*}{2013} & XI & $47 / 43$ & general profile & 3 January - 7 March \\
\cline { 2 - 5 } & XII & 30 & $\begin{array}{l}\text { female residents in Stawki } \\
\text { district }\end{array}$ & 10 May - 28 June \\
\cline { 2 - 5 } & XIII & $42 / 39$ & $\begin{array}{l}\text { female residents in Stawki } \\
\text { and Czerniewice districts }\end{array}$ & $\begin{array}{l}13 \text { September }-29 \\
\text { November }\end{array}$ \\
\hline
\end{tabular}




\begin{tabular}{|c|c|c|c|c|}
\hline Year & Edition & $\begin{array}{l}\text { Number of parti- } \\
\text { cipants/how many } \\
\text { finished }\end{array}$ & Target group & Date \\
\hline \multirow{4}{*}{2014} & XIV & $47 / 44$ & general profile & $\begin{array}{l}\text { mid-January - the end of } \\
\text { March }\end{array}$ \\
\hline & $\mathrm{XV}$ & 22 & $\begin{array}{l}\text { female residents in Podgórz } \\
\text { district }\end{array}$ & 15 April - 17 June \\
\hline & XVI & $40 / 35$ & $\begin{array}{l}\text { female residents in Rubinko- } \\
\text { wo district }\end{array}$ & 8 May - 26 June \\
\hline & XVII & $47 / 32$ & general profile & 2 October - 4 December \\
\hline \multirow{2}{*}{2015} & XVIII & $48 / 40$ & general profile & March - May \\
\hline & XIX & $23 / 15$ & general profile & 28 September - 7 December \\
\hline \multirow[t]{2}{*}{2016} & $\mathrm{XX}$ & 31 & $\begin{array}{l}\text { female residents in } \mathrm{Na} \\
\text { Skarpie district }\end{array}$ & April - June \\
\hline & XXI & $52 / 39$ & general profile & September - December \\
\hline \multirow{2}{*}{2017} & XXII & 52 & general profile & April - June \\
\hline & XXIII & 54 & general profile & October - December \\
\hline 2018 & \multicolumn{4}{|c|}{ no course organized } \\
\hline 2019 & XXIV & $53 / 30$ & general profile & no info \\
\hline
\end{tabular}

Source: Author's own work based on Sprawozdania z działalności Straży Miejskiej (for the years 2012-2019).

Main goals set by the city guards for the self-defence course for women include learning the right reactions and self-defence techniques useful in various dangerous situations as well as ways to avoid an attack (Winiarska, 2020). Moreover, the goal is to teach women the methods of preventing dangerous situations and proceeding during an assault. The participants of the course also learn how to use everyday objects in self-defence (Samorząd Studencki UMK w Toruniu, 2013). This falls within the scope of educational and preventive measures, as well as those aimed at reducing crime.

The training consists of two parts. The first part is self-defence training run by qualified instructors: Adrian Tabor, Tomasz Świerczyński, Jarosław Górecki, and Tomasz Pisarkiewicz. It includes twenty 90-minute classes usually conducted in several groups, held in the training room at the headquarters of the City Guard. In the second part, which is a 3-hour or 4-hour workshop, the participants together with an experienced psychologist Jarosław Paralusz discuss the main psychological aspects of security, e.g., how to recognize a possible victim and 
aggressor and how to control fear in an emergency. An important topic of the training is the preventive aspect - the participants learn how to avoid threats in public transport, a car, an apartment, or at a party (Paralusz, 2015). Course materials of these classes are internal documents and it is not possible to access them without joining the course. The participants enrol by phone. To complete the course, it is necessary to attend minimum $80 \%$ of classes (some of the women have failed to meet this requirement, and some have simply resigned). The offer is addressed to women of all ages. There have been also editions organized with District Councils and addressed to residents of individual districts.

Jestem bezpieczna trainings are promoted mainly through the City Guard website and the local media. Information about 2020 training addressed to female students was also on the website of the Faculty of Political Science and Security Studies at the Nicolaus Copernicus University (Kurs samoobrony, 2020). The City Guard in Torun also conducted classes for female students of pedagogy (Paralusz, 2016, June 13) as well as for women living and working in the old town, i.e., Nie bój się bronić [Do Not Be Afraid to Defend Yourself] (Paralusz, 2016, October 12). There have also been self-defence workshops for teenagers from secondary schools (Paralusz, 2017, February 3), employees of the Statistical Office in Bydgoszcz (Kowalski, 2015), students from the ERASMUS programme (Paralusz, 2017, March 21), tour guides, St. Brother Albert Aid Society in Toruń, employees of the Municipal Family Support Centre in Torun and the Poviat Labour Office in Toruń, employees of restaurants, and volunteers from "Powrót z U” (Society of Families and Friends of Child Addicts). There were also Aktywny, bezpieczny i zdrowy senior [An Active, Safe and Healthy Senior] seminars within the Miesiac dla zdrowia [Month for Health] campaign and the Watch Docs Festival. The City Guard invests in tools useful during the trainings - e.g., in a special outfit for the instructor and a dummy imitating the human torso (Manekin treningowy dla kobiet, 2016). This allows the participants to face the fear of experiencing pain, but also prepares them to deal with the possibility of harming someone. At the same time, this proves that self-defence is not treated as a single action to promote the City Guard in Torun. Good instructors know that these dozen-hour courses are not enough for the participants to be ready to repel any attack, but such trainings can motivate the women to look for further alternatives to continue their work towards the goals of the programme. 


\section{CONCLUSIONS}

"A woman should focus on remembering as many details about the attacker as possible"; "Participating in a self-defence course makes no sense, I will not learn anything there in such a short time"; "The techniques will not actually work as they do during the training", "I have no need to attend such classes"; "Women are fragile and cannot fight"; "You should not have dressed/behaved in this way / You should not have been walking there" - these are just some of the common misconceptions about the broadly understood self-defence of women which are still present in social awareness. There are also other objections expressed by women: "The techniques are too difficult"; "I have too little time to such a thing"; "I do not know if I could hit someone"; "I am too weak and thus something bad may happen to me during the training"; "My friends are not attending such classes, so why should I?"; "My husband will defend me" (Kaczmar, 2015).

Simple solutions promoted during some classes will not always be feasible, particularly when the attacker is prepared for them. Tim Larkin (2020) said that an average person will not be able to follow the scenario of "hit here and now kick there". Such a scenario does not actually exist because each situation is different and also because at the start of the fight your opponent's brain will work instinctively. There are no perfect solutions or perfect points to attack in self-defence, just as there are no good and bad ways of defence; they are only the effective and ineffective ones (Dougherty, 2015). The issue of self-defence should be approached with a deep understanding of problems, flexibility, and adaptation to the needs of the participants. Proper self-defence is designed to prevent a threat by quickly assessing the situation, recognizing warning signals, reacting appropriately, and taking the initiative.

For dozen years, the Jestem bezpieczna course has been part of actions undertaken to promote personal and structural security. It is worth mentioning that in Torun such trainings were also carried out by the Ministry of National Defence (in 2016 and 2018). The main intention of the organizers of the Samoobrona Kobiet [Women's Delf-Defence] project was to popularize among the civilians the training system of the Polish Armed Forces on hand-to-hand combat, to teach the basic self-defence techniques and to improve grappling and incapacitating in the area of self-defence (Ruszyt projekt Samoobrona Kobiet, 2016). It can be noticed that these assumptions are in line with those implemented locally by the City Guard. STAY AWAY (2020) seminars organized by International Krav Maga Federation $(2017,2018,2020)$ were another initiative to increase women's sense 
of security. Krav Maga itself was developed as a combat system for self-defence through simple methods, so it can also work for women. Jan Długosz (2018) in the article Samooszutwo confronts the concept of "crash courses in self-defence", promoted by the ministry, with the realities of training: already during the first class each instructor sees the differences in the initial potential between the participants - some of them have a naturally high level of coordination or low level of anxiety, while others cannot correctly repeat the simplest sequence of movements. These differences disappear with time, but real improvement requires at least two years of hard work in a constant cycle of two or three trainings a week. So what can you do during 12 trainings conducted in three months? Practically - nothing.

However, even a short course can change approach to personal safety and motivate participants and their environment for further work. Thus it would be a good idea to promote the Jestem bezpieczna course more widely in the media, especially on the Internet. Not every interested person will go to the City Guard website, but it is important that the information about the workshops reaches a large audience. This could be achieved through creating an official Facebook profile of the City Guard, which would inform about enrolment to the course, present its programme, and provide other relevant information. As the City Guard in Torun has a lot of experience, the training could be addressed also to other social or professional groups - such courses have already taken place.

Expanding the programme of psychological workshops and extending their time seems to be another idea for improving the course. Within a few hours it is difficult to convey and thoroughly discuss such issues as aggression, sources of stress, assertiveness, behaviour in extreme situations, crime prevention, and security measures and devices. Perhaps surveys should also be introduced before or after the course: in the first case - to find out what women would like to work on and what is important for them (Kruczyński \& Droździak, 2003). In the second case, such feedback after the course could help improve training methods. Successful defence in the face of a direct threat depends on: the ability to focus, experience, technical skills, physical fitness, individual mentality, knowledge of anatomy, and courage. Repelling an actual aggressor does not look like in the movies or staged fights, which present spectacular defence against several attackers - in fact, this is not a show in front of the audience, but a real situation (Skworz \& Larkin, 2014). Generally, for individuals and the society it is easier to build security through prevention rather than bear costs of crimes. 


\section{REFERENCES:}

Amrozy, K. (2018). Krav maga jako element bezpieczeństwa indywidualnego. In: J. Marszałek-Kawa, \& K. Chałubińska-Jentkiewicz (eds.). Spojrzenie na Azje (pp. 171-183). Toruń: Wydawnictwo Adam Marszałek.

Długosz, J.M. (2018, February 27). Samooszustwo [Kilka tygodni na naukę technik samoobrony to za mało]. Polityka, 9. Retrieved from: https://www.polityka.pl/tygodnikpolityka/ludzieistyle/1739344,1,kilka-tygodni-na-nauke-technik-samoobronyto-za-malo.read.

Dougherty, M.J. (2015). Jak się skutecznie bronić. Efektywna walka bez broni. Czerwonak: Wydawnictwo Vesper.

Harasymowicz, J. (2003). Godziwa samoobrona: etyczno-pragmatyczny model efektywnego przeciwdziałania agresji. In: A. Rakowski, A. Chodała, \& R.M. Kalina (eds.). Sporty ekstremalne $w$ przygotowaniu żotnierzy i formacji antyterrorystycznych (pp. 19-26). Warszawa: PTNKF SKFwW.

Höller, J., Maluschka, A., \& Reinisch, S. (2010). Samoobrona kobiet. Warszawa: Bellona. Retrieved from: https://books.google.pl/books?id=cJkFGY5puZoC\&printsec=fro ntcover\&hl $=\mathrm{pl} \# \mathrm{v}=$ onepage\& $\mathrm{q} \& \mathrm{f}=$ false.

International Krav Maga Federation (2020). Retrieved from: http://centrum-szkolenia. com.pl/.

Kaczmar, A. (2015). Podstawy samoobrony dla kobiet. Bytom: Fischer, Urząd Miasta.

Kowalska, M.M., \& Michalski, M.A. (2014). Utylitarne wartości współczesnych systemów walki wręcz - w trosce o bezpieczeństwo lokalne. In: A. Gałecki, A. Kurkiewicz, \& A. Mikołajczak (eds.). Infrastruktura krytyczna w procesie zarządzania w sytuacjach kryzysowych (pp. 465-473). Poznań: Wydawnictwo Wyższej Szkoły Bezpieczeństwa.

Kowalski, A. (2015, April 27). Seminarium z samoobrony dla ankieterów. Retrieved from: http://www.strazmiejska.torun.pl/aktualnosc-116-seminarium_z_samoobrony_dla_ankieterow.html.

Kruczyński, W., \& Droździak, P. (2003). Zawsze bezpieczna. Psychologiczne aspekty samoobrony kobiet. Warszawa: Prószyński i S-ka.

Kurs samoobrony (2020, February 25). Retrieved from: https://www.wnopib.umk.pl/ wiadomosci/?id=17007.

Larkin, T. (2020). Kiedy musisz się bronić. Łódź: Wydawnictwo Feeria.

Litwiniuk, A., \& Cynarski, W.J. (2003). Wychowawcze i utylitarne wartości uprawiania sportów i sztuk walki. In: W.J. Cynarski, \& K. Obodyński (eds.). Humanistyczna teoria sztuk i sportów walki. Koncepcje i problemy (pp. 123-128). Rzeszów: Wydawnictwo Uniwersytetu Rzeszowskiego.

Ludwinek-Zarzeka, I., \& Krupska, A. (2017, June 1). Kurs samoobrony dla kobiet. Czy to ma sens? "Lepiej być wyśmiana niż martwa" [WIDEO-INSTRUKTAŻ]. Retrieved from: https://kobieta.gazeta.pl/kobieta/7,107881,21889370,kurs-samoobrony-dlakobiet-czy-to-ma-sens-lepiej-byc-wysmiana.html. 
Manekin treningowy dla kobiet (2016). Retrieved from: http://www.um.torun.pl/pl/ manekin-treningowy-dla-kobiet.

Paralusz, J. (2015, December 15). Dyplomy za samoobronę. Retrieved from: http://www. strazmiejska.torun.pl/aktualnosc-307-dyplomy_za_samoobrone.html.

Paralusz, J. (2016, June 13). Weekendowa samoobrona dla studentów UMK. Retrieved from: http://www.strazmiejska.torun.pl/aktualnosc-492-weekendowa_samoobrona_dla_studentow_umk.html.

Paralusz, J. (2016, October 12). Rozpocząt się nabór na warsztaty z samoobrony dla kobiet ze starówki. Retrieved from: http://www.strazmiejska.torun.pl/aktualnosc618-rozpoczal_sie_nabor_na_warsztaty_z.html.

Paralusz, J. (2017, February 3). Zdrowo i sportowo ze Strażą Miejską. Retrieved from: http://www.strazmiejska.torun.pl/aktualnosc-736-zdrowo_i_sportowo_ze_straza_ miejska.html.

Paralusz, J. (2017, March 21). Samoobrona dla studentów z programu Erasmus. Retrieved from: http://www.strazmiejska.torun.pl/aktualnosc-771-samoobrona_dla_ studentow_z_programu.html.

Pokruszyński, W. (2011). Filozoficzne aspekty bezpieczeństwa. Józefów: Wydawnictwo Wyższej Szkoły Gospodarki Euroregionalnej im. Alcide De Gasperi.

Raczkowski, K. (2008). Sztuka walki i samoobrony w aspekcie historycznym, prawnym, psychologicznym. Warszawa: Centrum Doradztwa i Informacji Difin.

Ruszył projekt Samoobrona Kobiet (2016, November 20). Retrieved from: https://www. dorzeczy.pl/14990/ruszyl-projekt-samoobrona-kobiet.html.

Samoobrona dla kobiet (2020). Bądź kobietą nowoczesną. International Krav Maga Federation. Retrieved from: http://centrum-szkolenia.com.pl/samoobrona-dla-kobiet/.

Samorząd Studencki UMK w Toruniu (2013, April 4). Ogłoszenie. Retrieved from: https:// pl-pl.facebook.com/SamorzadStudenckiUMKwToruniu/posts/503391029720193/. Sikora, J., \& Domaradzki, G. (2011). Wydolność w samoobronie. Aspekt teoretyczny i praktyczny. Katowice: Wydawnictwo Szkoły Policji w Katowicach.

Skworz, J., \& Larkin, T. (2014, November 6). Samoobrona: najważniejsze 5 sekund Twojego życia. Women's Health. Retrieved from: https://www.womenshealth.pl/ lekcja-zycia/Samoobrona-najwazniejsze-5-sekund-Twojego-zycia,5529,2.

Sprawozdanie z działalności Straży Miejskiej w Toruniu za 2012 rok (2013). Retrieved from: http://www.strazmiejska.torun.pl/strona-36-sprawozdania.html.

Sprawozdanie z działalności Straży Miejskiej w Toruniu za 2013 rok (2014). Retrieved from: http://www.strazmiejska.torun.pl/strona-36-sprawozdania.html.

Sprawozdanie z działalności Straży Miejskiej w Toruniu za 2014 rok (2015). Retrieved from: http://www.strazmiejska.torun.pl/strona-36-sprawozdania.html.

Sprawozdanie z działalności Straży Miejskiej w Toruniu za 2015 rok (2016). Retrieved from: http://www.strazmiejska.torun.pl/strona-36-sprawozdania.html.

Sprawozdanie z działalności Straży Miejskiej w Toruniu za 2016 rok (2017). Retrieved from: http://www.strazmiejska.torun.pl/strona-36-sprawozdania.html.

Sprawozdanie z działalności Straży Miejskiej w Toruniu za 2017 rok (2018). Retrieved from: http://www.strazmiejska.torun.pl/strona-36-sprawozdania.html. 
Sprawozdanie z działalności Straży Miejskiej w Toruniu za 2018 rok (2019). Retrieved from: http://www.strazmiejska.torun.pl/strona-36-sprawozdania.html.

Sprawozdanie z działalności Straży Miejskiej w Toruniu za 2019 rok (2020). Retrieved from: http://www.strazmiejska.torun.pl/strona-36-sprawozdania.html.

STAY AWAY by IKMF samoobrona dla kobiet Toruń (2020). Retrieved from: https:// www.facebook.com/stayawaybyikmfsamoobronadlakobiet/.

Winiarska, M. (2020, February 26). Kurs samoobrony dla kobiet. Retrieved from: https:// www.torun.pl/pl/kurs-samoobrony-dla-kobiet-2. 